\title{
Competitive Capabilities of Thai Logistics Industry: Effects on Corporate Image and Performance
}

\author{
Apicha Boonpattarakan \\ School of Business Administration, Bangkok University \\ 119 Rama IV Road, Klongtoey, Bangkok 10110, Thailand \\ Tel: 66-2350-3500 ext.1640 E-mail: apicha1961@yahoo.com
}

Received: January 11, 2012

Accepted: January 31, 2012

Published: March 1, 2012

doi:10.5539/ijbm.v7n5p19

URL: http://dx.doi.org/10.5539/ijbm.v7n5p19

\begin{abstract}
This study was carried out to investigate competitive capabilities of firms operating in the logistics industry. The objective of the research was to study the effects of strategic elements associated with competitive capabilities on corporate image, profitability, and growth. Key strategic elements for building competitive capabilities were proposed to consist of service quality, marketing capabilities, and management capabilities. The results suggest that the firms' first priority level in building competitive capabilities must rest on rendering reliable and speedy services, providing varying services, and offering attractive prices. The second priority level is to provide rapid customer response, make service facilities available and attractive, make sure that service location is convenient for access, and utilize up-to-date IT to improve service operations.
\end{abstract}

Keywords: Competitive capabilities, Service quality, Marketing capabilities, Management capabilities, Corporate image, Corporate performance

\section{Introduction}

Globalization and technological evolution have significantly enhanced the potential of free trade around the world. Consequently, global competition has become more and more intense. Survival in the age of free trade will undoubtedly depend of building sustainable competitive capabilities, which may include a variety of key competencies, such as speed, reliability, responsiveness, product quality, and appropriateness of marketing and management strategies. In order to survive and succeed in the market, firms will have to focus on building corporate strengths and competitive capabilities.

Increasing attention has recently been focused on logistics costs among firms in Thailand. Logistics costs can be categorized into inventory costs, transportation costs, and administrative costs. The logistics cost in Thailand is as high as 18-20 percent of its gross domestic product (GDP). In comparison, Singapore and Malaysia's logistics costs are approximately 8 percent and 13 percent of their GDPs (Mohan, 2008). In addition, Thailand's logistics costs are much higher than those of developed countries. Office of the National Economic and Social Development Board of Thailand reports that the logistics costs of Thailand in 2008 and 2009 are $18.6 \%$ and $16.8 \%$, whereas the logistics costs of U.S.A. are reported to be $9.3 \%$ in 2008 and $7.7 \%$ in 2009 respectively (Thailand Logistics Report, 2010). Evidently, the high logistics costs have significantly reduced the competitive capabilities of corporations operating in Thailand.

Enhancing logistics service providers' capabilities will help reduce their internal costs and service fees/prices. Firms using logistics services will pay less for services received, leading to the improvement of their competitiveness in the market and around the world. Therefore, focusing on enhancing logistics firms' competitive capabilities will be of major concern for Thailand. Hence, our research objective was to study the effects of competitive capabilities on corporate image and performance (in terms of profitability and growth) among logistics firms in Thailand.

\section{Literature Review}

\subsection{Logistics Operations and Capabilities}

Logistics is a critical part of supply chain management. The Council of Supply Chain Management Professionals (CSCMP) defines logistics as "part of supply chain management that plans, implements, and controls the 
efficient, effective forward and reverse flow and storage of goods, services, and related information between the point of origin and the point of consumption in order to meet customers' requirements. Logistics management is an integrating function which coordinates and optimizes all logistics activities, as well as integrates logistics activities with other functions, including marketing, sales, manufacturing, finance, and information technology" (Supply Chain Management: Terms and Glossary, 2010). This definition implies that logistics function cannot work and succeed by itself; it has to work with all other functions in the firms. The resource-based view (RBV) suggests that capabilities of firms are considered key resources that can be used to build sustainable competitive advantage (Oliver, 1997). This belief suggests that logistics capability is a key strategic resource used to build competitive advantage (Bowersox, Closs, \& Stank, 1999; Lynch, Keller, \& Ozment, 2000).

Logistics capabilities are firms' resources, such as assets, competencies, processes, and knowledge, which help firms to enhance and improve organizational efficiency and effectiveness (Barney, 1991). There have been numerous studies regarding the link between logistics capabilities and firms' competitive advantage and performance (Ellinger, Daugherty, \& Keller, 2000; Zhao, Droge, \& Stank, 2001). Enz (2008) suggests building competitive advantage by managing key resources such as physical resources, human resources, organizational knowledge and learning, and alliances/networks. Thus, to increase competitive advantage and improve performance, firms must identify those key strategic elements associated with their business and try to excel in them. In this study, three categories of strategic elements related to competitive capabilities have been identified. These are service quality, marketing capabilities, and management capabilities.

\subsection{Service Quality}

The concept of service quality has been proposed as a key determinant to customer satisfaction (Juran \& Godfrey, 1999). Parasuraman, Zeithaml, and Berry (1985) together with Grönroos (1984) consider service quality as the difference between customers' expectation and actual performance. Hoffman and Bateson (2001), on the other hand, define service quality as an attitude, i.e., the overall evaluation of a brand or service's performance. Grönroos (1984) suggests three dimensions of service quality, i.e., technical quality, functional quality, and corporate image. Technical quality simply means what customers get from using the service. Functional quality refers to the way the service is provided and delivered to customers. Corporate image is deemed to be the results of the first two dimensions and also the results of some other strategic elements of the firm, such as the convenience of location, the attractiveness of the price, and the quality of employees.

Parasuraman et al. (1985) identified and studied the dimensions of service quality. In the beginning, ten key service quality determinants were identified. These consisted of reliability, responsiveness, competence, access, courtesy, communication, credibility, security, understanding/knowing the customer, and tangibles. Later, these determinants were redefined and grouped into five dimensions, i.e., tangibles, reliability, responsiveness, assurance, and empathy (Parasuraman, Zeithaml, \& Berry, 1988). According to Parasuraman et al. (1988, p.23), tangibles refer to "the appearance of physical facilities, equipment, appearance of personnel, and communication materials." Reliability is referred to as "the ability to perform the promised service dependably and accurately." Responsiveness is defined as "the willingness to help customers and provide prompt service." Assurance means "the knowledge and courtesy of employees and their ability to inspire trust and confidence." Empathy, the last dimension, is defined as "the caring, individualized attention the firm provides to its customers."

\subsection{Marketing Capabilities}

Marketing capabilities are considered a key element enhancing firms' performance (Hunt \& Morgan, 1996). Marketing capabilities can be defined in various ways, e.g., providing attractive promotion, having external-market knowledge, and rendering good customer service (Moore \& Fairhurst, 2003). In this study, pricing and location are considered two key marketing capabilities affecting logistics firms' performance. Price is considered an essential marketing strategy. It basically means the amount of money given in consideration for the sale of products or services (Kotler \& Keller, 2006). Value prices appear to help attract consumers and increase sales. Location of firms is also a significant marketing decision influencing customer service leading to increased performance (Kotler \& Keller, 2006). It has long been considered a strategic factor in retailing and services. The convenience of location is a must for services that require buyer-seller interaction; it is considered vital for retail and service operators (Jones, Mothersbaugh, \& Beatty, 2003; Wood \& Browne, 2007).

\subsection{Management Capabilities}

Organizational learning is an essential component for building firms' competitive advantage (Goh \& Ryan, 2008). There are research studies that show the linkage between learning and performance (Elliott \& Goh, 2006). It is believed that organizations that learn to utilize state-of-the-art management techniques and technologies will 
be able to excel. Likewise, human capital is believed to be a vital part of organizational success. Research shows that employee satisfaction leads to customer satisfaction and corporate success (Burke, Graham, \& Smith, 2005). Competent employees with good skills will be able to help organizations provide better services, leading to customer satisfaction, and increased corporate image. In the era of free trade and competitive intensity, a strategic alliance or business network is a must for firms to succeed; it can be used to build competitive advantage (Cante, Calluzzo, Schwartz, \& Schwartz, 2004). Business networks and alliances represent new organizational paradigm that seeks to achieve better performance through collaboration than through competition (Todeva \& Knoke, 2006). Thus, it is believed that firms who can build strong business networks will have greater opportunities to succeed.

\subsection{Corporate Image and Performance}

Corporate image is the consumer's response to the total offering and may be deemed as the sum of beliefs, ideas, and impressions that the public has of an organization. It is often related to the perceived quality of products or services (Nguyen \& Leblanc, 2001). Corporate image may be considered a function of the accumulation of consumption experience overtime and has two principal components: functional and emotional. The functional component is related to tangible attributes that can be easily measured, while the emotional component is associated with psychological dimensions that are manifested by feelings and attitudes towards an organization (Weiwei, 2007). The concept of corporate image has been extensively studied in the past. It has been defined as consumer evaluation of salient attributes, which could be tangible and intangible or functional and psychological (Thompson \& Chen, 1998). Corporate image is, therefore, the result of an aggregate process by which customers compare and contrast the various attributes of organizations. In the present competitive environment, corporate image is perceived to have strategic value for the firms and to be a key strategic element enhancing firm performance and society's perception. In addition, corporate image is considered to have a potential effect on customer loyalty toward the firm (Andreassen \& Lindestad, 1998; Romaniuk \& Sharp, 2008).

Corporate performance can be measured using quantitative or qualitative indicators (Kim, 2009). These measures provide a tool for firms to manage progress towards achieving goals. Performance measurement is thus the process of assessing the progress made towards achieving the predetermined goals. Measurement is managed using output measures and outcome measures. Output measures are used to evaluate performed activities or efforts in quantitative or qualitative terms. On the other hand, outcome measures are used to evaluate the firm's results in comparison to its intended goals (Performance Measures, 2009). Both qualitative and quantitative measures have been proposed and studied in the past. Qualitative measures of performance include effectiveness (Boyle \& Dwyer, 1995; Bucklin \& Sengupta, 1993), customer satisfaction (Fonseca, 2009), and performance relative to industry norm (Heide \& Stump, 1995). On the other hand, quantitative measures of performance include profitability, sales growth, ratio between costs and income (Yee, Yeung, \& Cheng, 2008), inventory turnover, percentage of on-time delivery, and percentage of acceptable bearings delivered (Noordewier, John, \& Nevin, 1990). Corporate performance has been considered as the outcome of the firm resulting from corporate strategies. In this study, performance was measured through profitability and growth rate.

\section{Development of Conceptual Framework}

Based on previous research described above, the study's conceptual framework was developed by identifying key strategic elements associated with service quality, marketing capabilities, and management capabilities, and linking them to corporate image and performance. The strategic elements concerning service quality identified in this study consist of reliability of service, speed of service, service flexibility, service safety, ease of service access, rapid customer response, availability of service facilities, and variety of services offered. For marketing capabilities, the focus was on two key elements, i.e., reasonableness of price and convenience of location, whereas for management capabilities the emphasis was on IT application, employee development, and business network expansion. This leads to the development of the conceptual framework shown in Figure 1.

\section{Insert Figure 1 here}

The definitions of all the relevant variables included in this study are presented in Table 1.

\section{Insert Table 1 here}

\section{Research Methodology}

The population of interest was confined to the list of logistics firms compiled by the Department of Business Development, Ministry of Commerce, Thailand (Business Database, 2008). The total number of population was 15,244. Sample size was determined using the rule of Taro Yamane's with confidence level of $95 \%$ and error of $5 \%$ (Yamane, 1967). The sample size computed was 390. Since the response rate was expected to be around $30-$ 
$32 \%$, the total sample size used in this study was expanded to 1,200 . Then, simple random sampling was used to draw a sample size of 1,200 .

The first draft of the questionnaire used in the survey was developed. The majority of scales measuring key constructs were based on existing measures. Then, a panel of five academic experts was asked to help evaluate the content of the questionnaire. After that, modifications were carried out and a formal pretest with 30 entrepreneurial firms was taken to check the reliability and validity of the questions. Comments were evaluated and the questionnaire was modified to reflect the true meaning of the questions. The final questionnaire was then administered to a sample of 1,200 firms. Firms were contacted first by phone and asked for their cooperation and the questionnaire was sent to them by fax. One week after the questionnaire was sent a telephone follow up was carried out.

\section{Analysis and Results}

\subsection{Sample Characteristics}

The total number of completed questionnaires received was 299 , representing a response rate of $24.92 \%$. Among these, $29.43 \%$ were from land transportation firms; $25.08 \%$ were from water transportation firms; $3.01 \%$ were from air transportation firms; $15.38 \%$ were from warehousing service providers; and $27.09 \%$ were from freight forwarders and custom brokers.

$68.65 \%$ of firms were under the classification of small and medium enterprises with yearly income under Baht 100 million. $22.22 \%$ of firms had yearly income of more than Baht 200 million, followed by $9.13 \%$ of firms with yearly income in the range of Baht100 - 200 million. With regard to the number of employees, $68.18 \%$ of firms had less than 100 employees, followed by $100-500$ employees $(23.87 \%)$, and more than 500 employees (7.95\%).

The average number of years the logistics firms in the sample had been in the business was 14.13 years with standard deviation of 11.41 years. The majority of firms, i.e., $85.45 \%$, had Thai shareholders, whereas $14.55 \%$ of firms had foreign shareholders.

\subsection{Industry Structure and Characteristics}

\subsubsection{Industry Structure}

With regard to the industry structure, the respondents indicated that intense competition and a large number of competitors $(22.19 \%$ and $20.52 \%)$ were of major forces in the industry, followed by high customer bargaining power $(15.42 \%)$, ease of entry (12.79\%), and small sized competitors (10.24\%). Details of factors influencing industry structure are presented in Table 2 .

\section{Insert Table 2 here}

\subsubsection{Recognized Logistics Service Providers}

Customers were asked to rank those prominent logistics firms in Thailand. The results indicated that large firms in the logistics industry were well known by customers, especially those foreign logistics firms in Thailand, such as NYK, DHL, CEVA, KLINE, NIPPON, and MAERSK. These foreign firms were well recognized by customers in this industry, whereas only a few Thai firms were well-known and recognized by customers in the industry. The Thai firms mentioned were Cementhai Logistics and Thai Airways International.

\subsubsection{Competitive Intensity}

We asked about the competitive intensity using a five point scale ranging from highest, high, medium, low, to lowest. The results indicated that the majority of firms with $79.76 \%$ said that the intensity of competition was high to highest, whereas $16.92 \%$ of firms stated that the intensity level of competition was medium and merely $3.32 \%$ said that the intensity of competition was low to lowest.

\subsubsection{Key competitive Capabilities in the Industry}

Respondents were asked to indicate the important level of each factor associated with competitive success. The results indicated that only five key factors scored high on the scale. These five factors were regarded as key competitive capabilities in the industry. They consisted of rapid response to customer needs, service safety, service speed, service support, and service flexibility.

\subsubsection{Obstacles in the Industry}

When asked about obstacles that hindered the operations in the logistics industry in Thailand, respondents indicated that on-going economic uncertainty was a major concern (33.73\%), followed by lack of knowledgeable 
personnel (19.56\%), non-supportive laws (15.33\%), lack of good infrastructure (14.47\%), difficulty of locating source of capital $(8.16 \%)$, and others $(8.75 \%)$.

\subsection{Effects of Competitive Capabilities on Corporate Image and Performance}

Multiple regression analysis using ordinary least square was used to analyze the conceptual framework. Three regression models were developed to test the proposed model. The first model was concerned with the effects of strategic elements associated with service quality, marketing capabilities, and management capabilities on corporate image. The results are reported in Table 3. The values of variance inflation factors (VIF) suggested no multicollinearity problem; the values were much lower than 10 (Hair, Black, Babin, Anderson, \& Tatham, 2006). The test results showed that rapid customer response, availability of service facilities, reasonableness of price, and IT application had significant effects on corporate image $(\mathrm{p}<0.001)$. Speed of service and variety of services offered were also found to significantly affect corporate image $(\mathrm{p}<0.01)$. In addition, reliability of service and employee development also had significant effects on corporate image $(\mathrm{p}<0.05)$. Service flexibility, service safety, ease of service access, convenience of location, and business network expansion were found to have no effects on corporate image.

\section{Insert Table 3 here}

The second model involved determining the effects of those strategic elements on profitability. The results are reported in Table 4. The values of variance inflation factors (VIF) suggested no multicollinearity problem; the values were lower than 10 (Hair et al. 2006). The test results showed that variety of services offered and convenience of location had significant effects on profitability $(\mathrm{p}<0.001)$. Rapid customer response and reasonableness of price were also found to significantly affect profitability $(\mathrm{p}<0.01)$. Likewise, reliability of service and speed of service had significant effects on profitability $(\mathrm{p}<0.05)$. Service flexibility, service safety, ease of service access, and availability of service facilities, IT application, employee development, and business network expansion were found to have no significant effects on profitability.

\section{Insert Table 4 here}

The third model was designed to study the effects of the proposed strategic elements on growth. The results are reported in Table 5. The values of variance inflation factors (VIF) were much lower than 10 suggesting no multicollinearity problem (Hair et al., 2006). The test results showed that reliability of service, speed of service, ease of service access, and reasonableness of price had significant effects on growth $(p<0.001)$. Availability of service facilities and convenience of location were also found to significantly affect growth $(p<0.01)$. Variety of services offered and IT application were also found to have a significant effect on growth $(p<0.05)$. On the other hand, service flexibility, service safety, and rapid customer response, employee development, and business network expansion were found to have no effects on growth.

\section{Insert Table 5 here}

\subsection{Effects of Corporate Image on Performance}

We also investigated the effects of corporate image on profitability and growth using simple regression analysis with ordinary least square. The results showed that corporate image significantly affected both profitability $($ Standardized Beta $=0.486, \mathrm{t}$-value $=9.580, \mathrm{p}<0.001)$ and growth $($ Standardized Beta $=0.602, \mathrm{t}$-value $=12.986$, $\mathrm{p}<0.001)$.

\section{Discussion}

It was found that competition in the logistics industry is very intense. The intensity level perceived by logistics firms was considered to be high to highest. This is due to the fact that barriers to entry in this industry are low. Currently, there are a large number of competitors in the industry and new competitors can easily enter the market. Therefore, firms operating in this industry have to think strategically and try to differentiate themselves from others by providing better and needed services if they wish to survive and be successful.

Corporate image was found to be influenced by five strategic elements related to service quality. This was consistent with the study of Ryu, Lee, and Kim (2011). These elements consist of reliability of service, speed of service, rapid customer response, availability of service facilities, and variety of services offered. Price is the only marketing capability that has a strong influence on corporate image. Convenient location was not found to influence corporate image. For management capabilities, only IT application and employee development were found to influence corporate image. In sum, it was found that the three most important determinants enhancing corporate image are IT application, pricing, and availability of service facilities. The results indicate that the image of logistics firms is primarily based on these three key factors. In addition, logistics firms may also need 
to pay close attention to those service quality aspects of the firms, which are considered to be the driving forces of the success in the industry.

Past research has shown that service quality can be adopted as a competitive weapon influencing firms' performance (Ramayah, Samat, \& Lo, 2011; Rapert \& Wren, 1998). In this study, it was found that four strategic elements of service quality influenced profitability. These elements consist of reliability of service, speed of service, rapid customer response, and variety of services offered. Both pricing and convenient location related to marketing capabilities are of important factors influencing profitability. In this case, the three most important strategic elements are variety of services offered, convenience of location, and pricing. Logistics firms may need to set priorities and focus their operations on these three variables. However, no management capabilities were found to have an impact on corporate profitability. This may be due to the fact that these elements are considered internal factors influencing the efficiency of internal operations. Thus, it may not have a direct influence on corporate profitability. With regard to growth, five strategic elements of service quality are found to significantly impact growth. Both pricing and convenient location are vital for corporate growth. For management capabilities, only IT application is deemed to have an effect on growth. The three strongest strategic elements influencing growth are ease of service access, pricing, and reliability of service.

Table 6 provides a comparison of the effects of competitive capabilities on corporate image, profitability, and growth. In order to build competitive capabilities, firms must set priorities on implementing those strategic elements. Firms must focus their first priority on rendering services with reliability and speed, providing a variety of services to choose from, and responding to customer needs with attractive pricing strategy. The second level of priority should be focused on strategic elements related to providing rapid customer response, making service facilities available and more attractive, making sure that the contact location is convenient for access, and adopting and implementing up-to-date IT technology for service operations.

\section{Insert Table 6 here}

This research contributes to the literature on competitive capabilities among firms operating in the logistics industry by investigating the effects of key strategic elements associated with competitive capabilities on corporate image and performance. The results provide direction for those who are interested in this area of research. Nevertheless, this study is limited in the sense that it only focused on those thirteen strategic elements identified in the conceptual framework. Other strategic elements, such as innovation, promotion, and employee satisfaction, were not included in the model. Propensity to continue the relationship was also left out of the model. In addition, the study simply collected data from firms operating in the logistics industry. Future research is called for to investigate the application of the above mentioned model to firms operating in other service industries, such as tourism, spa, and restaurant industries, as well as to compare competitive capabilities across different service industries.

\section{Conclusion}

Competition among firms operating in the logistics industry has become more and more intense with a large number of service providers. Firms competing in this industry are required to adapt and adjust. They must focus on building competitive capabilities by emphasizing service quality, marketing capabilities, and management capabilities. The results of this research show that the key service quality dimensions on which firms must strongly emphasize are reliability and speed of services as well as providing a variety of services customers can choose from. Pricing is also a very important strategic element firms need to pay close attention to. Service fees must be reasonable and attractive to customers. The focal point is to improve competitive capabilities while reducing firms' operating costs and prices.

\section{References}

Andreassen, T. W., \& Lindestad, B. (1998). The effect of corporate image in the formation of customer loyalty. Journal of Service Research, 1(1), 82-92. http://dx.doi.org/10.1177/109467059800100107

Barney, J. (1991). Firm resources and sustained competitive advantage. Journal of Management, 17(1), 90-120. http://dx.doi.org/10.1177/014920639101700108

Bowersox, D. J., Closs, D. J., \& Stank, T. P. (1999). 21st century logistics: making supply chain integration a reality. Oak Brook, IL: Council of Logistics Management.

Boyle, B. A., \& Dwyer, F. R. (1995). Power, bureaucracy, influence, and performance: their relationships in industrial distribution channels. Journal of Business Research, 32(3), 189-200. http://dx.doi.org/10.1016/0148-2963(94)00045-G 
Bucklin, L. P., \& Sengupta, S. (1993). Organizing successful co-marketing alliances. Journal of Marketing, 57(2), 32-46. http://dx.doi.org/10.2307/1252025

Burke, R. J., Graham, J., \& Smith, F. (2005). Effects of reengineering on the employee satisfaction-customer satisfaction relationship. The TQM Magazine, 17(4), 358-363. http://dx.doi.org/10.1108/09544780510603198

Business Database. (2008). [Online] Available: http://knowledgebase.dbd.go.th/dbd/Main/login.aspx (September $16,2008)$

Cante, C. J., Calluzzo, V. J., Schwartz, D. P., \& Schwartz, T. M. (2004). Strategic alliances in food and beverage and executive recruiting industries. Supply Chain Management: An International Journal, 9(3), 230-240. http://dx.doi.org/10.1108/13598540410544926

Ellinger, A. E., Daugherty, P. J., \& Keller, S. B. (2000). The relationship between marketing/logistics interdepartmental integration and performance in us manufacturing firms: an empirical study. Journal of Business Logistics, 21(1), 1-22.

Elliott, C., \& Goh, S. C. (2006). Organizational learning and performance outcomes: a review of the empirical literature and measurement of the construct. In The ASAC Annual Conference, May, Ottawa.

Enz, C. A. (2008). Creating a competitive advantage by building resource capability: the case of outback steakhouse Korea. Cornell Hospitality Quarterly, 49(1), 73-78. http://dx.doi.org/10.1177/1938965507311648

Fonseca, J. R. S. (2009). Customer satisfaction study via a latent segment model. Journal of Retailing and Consumer Services, 16(5), 352-359. http://dx.doi.org/10.1016/j.jretconser.2009.04.001

Goh, S. C., \& Ryan, P. J. (2008). The organizational performance of learning companies: a longitudinal and competitor analysis using market and accounting financial data. The Learning Organization, 15(3), 225-239.

Grönroos, C. (1984). A service quality model and its marketing implications. Journal of the Academy of Marketing Science, 24(1), 36-44.

Hair, J. F., Black, W. C., Babin, B. J., Anderson, R. E., \& Tatham, R. L. (2006). Multivariate data analysis. (6th ed.). Upper Saddle River, N.J.: Prentice Hall.

Heide, J. B., \& Stump, R. L. (1995). Performance implications of buyer-supplier relationships in industrial markets. Journal of Business Research, 32(1), 57-66. http://dx.doi.org/10.1016/0148-2963(94)00010-C

Hoffman, K. D., \& Bateson, J. E. (2001). Essentials of services marketing: concepts, strategies, and cases. Chula Vista, CA: South-Western College Publishing.

Hunt, S. D., \& Morgan, R. M. (1996). The resource-advantage theory of competition: dynamics, path dependencies, and evolutionary dimensions. Journal of Marketing, 60(4), 107-114. http://dx.doi.org/10.2307/1251905

Jones, M. A., Mothersbaugh, D. L., \& Beatty, S. E. (2003). The effects of locational convenience on customer repurchase intentions across service types. Journal of Services Marketing, 17(7), 701-712. http://dx.doi.org/10.1108/08876040310501250

Juran, J. M., \& Godfrey, B. (1999). Juran's quality handbook. (5 ${ }^{\text {th }}$ ed.). New York: McGraw-Hill.

Kim, S. W. (2009). An investigation on the direct and indirect effect of supply chain integration on firm performance. International Journal of Production Economics, 119(2), 328-346. http://dx.doi.org/10.1016/j.ijpe.2009.03.007

Kotler, P., \& Keller, K. L. (2006). Marketing management. (12 ${ }^{\text {th }}$ ed.). Upper Saddle River, NJ: Prentice Hall.

Lynch, D. F., Keller, S. B., \& Ozment, J. (2000). The effects of logistics capabilities and strategy on firm performance. Journal of Business Logistics, 21(2), 47-67.

Mohan, D. (2008). Thailand as ASEAN logistics hub: possibilities and challenges. Logistics Digest. [Online] Available: http://www.logisticsdigest.com/index.php?option=com_content\&. task=view\&id=281 (October 13, 2008)

Moore, M., \& Fairhurst, A. (2003). Marketing capabilities and firm performance in fashion retailing. Journal of Fashion Marketing and Management, 7(7), 386-397. http://dx.doi.org/10.1108/13612020310496976

Nguyen, N., \& Leblanc, G. (2001). Corporate image and corporate reputation in customers' retention decisions in services. Journal of Retailing and Consumer Services, 8(4), 227-236. http://dx.doi.org/10.1016/S0969-6989(00)00029-1 
Noordewier, T. G., John, G., \& Nevin, J. R. (1990). Performance outcomes of purchasing arrangements in industrial buyer-vendor relationships. Journal of Marketing, 54(4), 80-93. http://dx.doi.org/10.2307/1251761

Oliver, C. (1997). Sustainable competitive advantage: combining institutional and resource based view. Strategic Management Journal, 697-713. http://dx.doi.org/10.1002/(SICI)1097-0266(199710)18:9<697::AID-SMJ909>3.0.CO;2-C

Parasuraman, A., Zeithaml, V. A., \& Berry, L. L. (1985). A conceptual model of service quality and its implications for future research. Journal of Marketing, 49(3), 41-50. http://dx.doi.org/10.2307/1251430

Parasuraman, A., Zeithaml, V. A., \& Berry, L. L. (1988). SERVQUAL: A multiple-item scale for measuring consumer perceptions of service quality. Journal of Retailing, 64(1), 12-40.

Performance Measures. (2009). [Online] Available: http://www.cio.ny.gov/pmmp/ guidebook2/Performance.pdf (April 13, 2009)

Ramayah, T., Samat, N., \& Lo, M.C. (2011). Market orientation, service quality and organizational performance in service organizations in Malaysia. Asia Pacific Journal of Business Administration, 3(1), 8-27. http://dx.doi.org/10.1108/17574321111116379

Rapert, M.I., \& Wren, B.M. (1998). Service quality as a competitive opportunity. The Journal of Services Marketing, 12(3), 223-235. http://dx.doi.org/10.1108/08876049810219539

Romaniuk, J., \& Sharp, B. (2008). The Relationship between corporate/brand image and customer loyalty: A replication. [Online] Available: http://smib.vuw.ac.nz:8081/www/ANZMAC1999/Site/R/Romaniuk.pdf(October 13, 2008)

Ryu, K., Lee, H.R., \& Kim, W. G. (2011). Influence of the quality of physical environment, food, and service on restaurant image, value, customer satisfaction, and behavioral intentions. International Journal of Contemporary Hospitality Management, 24(2), (In Press).

Supply Chain Management: Terms and glossary. (2010). [Online] Available: http://cscmp.org/Resources/Terms.asp.(October 16, 2010)

Thailand Logistics Report 2010. (2011). [Online] Available: http://www.nesdb.go.th/Portals/0/tasks/dev_logis/report/data_0247140111.pdf (December 25, 2011)

Thompson, K. E., \& Chen, Y. L. (1998). Retail store image: a means-end approach. Journal of Marketing Practice, 4(6), 161-173. http://dx.doi.org/10.1108/EUM0000000004528

Todeva, E., \& Knoke, D. (2006). Strategic alliances and models of collaboration. Management Decision, 43(1), 123-148. http://dx.doi.org/10.1108/00251740510572533

Weiwei, T. (2007). Impact of corporate image and corporate reputation on customer loyalty: a review. Management Science and Engineering, 1(2), 57-62.

Wood, S., \& Browne, S. (2007). Convenience store location planning and forecasting - a practical research agenda. International Journal of Retail \& Distribution Management, 35(4), 233-255. http://dx.doi.org/10.1108/09590550710736184

Yamane, T. (1967). Statistics, an introductory analysis. New York: Harper and Row

Yee, R. W. Y., Yeung, A. C. L., \& Cheng, T. C. E. (2008). The impact of employee satisfaction on quality and profitability in high-contact service industries. Journal of Operations Management, 26(5), 651-668. http://dx.doi.org/10.1016/j.jom.2008.01.001

Zhao, M., Droge, C., \& Stank, T. P. (2001). Effects of logistics capabilities on firm performance: customer-focused versus information-focused capabilities. Journal of Business Logistics, 22(2), 91-107. http://dx.doi.org/10.1002/j.2158-1592.2001.tb00005.x 
Table 1. Definitions of Relevant Variables

\begin{tabular}{|c|c|}
\hline Variables & Definitions \\
\hline Reliability of Service & The firms' ability to perform services dependably and accurately \\
\hline Speed of Service & The firms' ability to perform services rapidly \\
\hline Service Flexibility & $\begin{array}{l}\text { The firms' ability to adapt to unexpected circumstances; services can be } \\
\text { modified to fit the changes in customers' needs }\end{array}$ \\
\hline Service Safety & The firms' ability to provide services with high quality and high safety \\
\hline Ease of Service Access & The firms' ability to provide ease of access to use services \\
\hline Rapid Customer Response & $\begin{array}{l}\text { The firms' willingness to respond to customers' needs and questions with } \\
\text { rapidity }\end{array}$ \\
\hline $\begin{array}{l}\text { Availability of Service } \\
\text { Facilities }\end{array}$ & $\begin{array}{l}\text { The availability and appearance of physical facilities, tools, and } \\
\text { equipment necessary to perform services }\end{array}$ \\
\hline Variety of Services Offered & Various forms and types of services offered to customers \\
\hline Reasonableness of Price & Offering reasonable prices with good values \\
\hline Convenience of Location & The convenient location of service facilities \\
\hline IT Application & The application of IT to firms' operations \\
\hline Employee Development & $\begin{array}{l}\text { The extent of the training programs designed to develop high quality } \\
\text { employees }\end{array}$ \\
\hline Business Network Expansion & $\begin{array}{l}\text { The extent to which firms form strategic alliance or network with other } \\
\text { firms. }\end{array}$ \\
\hline Corporate Image & The sum of beliefs, ideas, and impressions that the public has of the firm \\
\hline Profitability & The change in profitability when compared to last year's profitability \\
\hline Growth & The growth level of the firm when compared to last year's sales level \\
\hline
\end{tabular}

Table 2. Factors Influencing Industry Structure

\begin{tabular}{|l|c|}
\hline \multicolumn{1}{|c|}{ Factors } & Percentage \\
\hline The competition is very intense. & 22.19 \\
\hline There are a large number of competitors in the industry. & 20.52 \\
\hline Customers have high bargaining power. & 15.42 \\
\hline New competitors can easily enter the industry. & 12.79 \\
\hline Most competitors are of small size. & 10.24 \\
\hline Logistical services are essentially needed by customers. & 8.79 \\
\hline The industry is continuously growing. & 6.94 \\
\hline The profitability earned is satisfactory. & 2.60 \\
\hline others & 0.51 \\
\hline
\end{tabular}


Table 3. Effects of Competitive Capabilities on Corporate Image

\begin{tabular}{|l|c|c|c|c|}
\hline \multicolumn{1}{|c|}{ Strategic Elements } & Standardized Beta & t-value & p-value & VIF \\
\hline Reliability of Service & 0.095 & 2.223 & $0.027^{*}$ & 1.955 \\
\hline Speed of Service & 0.139 & 2.763 & $0.006^{* *}$ & 2.709 \\
\hline Service Flexibility & -0.006 & -0.150 & 0.881 & 1.719 \\
\hline Service Safety & 0.010 & 0.254 & 0.800 & 1.557 \\
\hline Ease of Service Access & -0.035 & -1.013 & 0.312 & 1.275 \\
\hline Rapid Customer Response & 0.175 & 4.226 & $0.000^{* * *}$ & 1.852 \\
\hline Availability of Service Facilities & 0.243 & 5.850 & $0.000^{* * *}$ & 1.853 \\
\hline Variety of Services Offered & 0.104 & 2.942 & $0.004 * *$ & 1.333 \\
\hline Reasonableness of Price & 0.207 & 6.076 & $0.000^{* * *}$ & 1.247 \\
\hline Convenience of Location & -0.029 & -0.794 & 0.428 & 1.414 \\
\hline IT Application & 0.280 & 7.332 & $0.000^{* * *}$ & 1.573 \\
\hline Employee Development & 0.100 & 2.289 & $0.023 *$ & 2.046 \\
\hline Business Network Expansion & -0.018 & -0.520 & 0.603 & 1.348 \\
\hline
\end{tabular}

$\mathrm{R}^{2}=0.739, \mathrm{~F}=61.145, \mathrm{p}$-value $=0.000$

*** Significant at 0.001

** Significant at 0.01

* Significant at 0.05

Table 4. Effects of Competitive Capabilities on Profitability

\begin{tabular}{|l|c|c|c|c|}
\hline \multicolumn{1}{|c|}{ Strategic Elements } & $\begin{array}{c}\text { Standardized } \\
\text { Beta }\end{array}$ & t-value & p-value & VIF \\
\hline Reliability of Service & 0.123 & 1.984 & $0.048^{*}$ & 1.955 \\
\hline Speed of Service & 0.151 & 2.074 & $0.039^{*}$ & 2.709 \\
\hline Service Flexibility & -0.036 & -0.629 & 0.530 & 1.719 \\
\hline Service Safety & 0.043 & 0.771 & 0.442 & 1.557 \\
\hline Ease of Service Access & 0.046 & 0.929 & 0.354 & 1.275 \\
\hline Rapid Customer Response & 0.157 & 2.605 & $0.010 * *$ & 1.852 \\
\hline Availability of Service Facilities & -0.020 & -0.335 & 0.738 & 1.853 \\
\hline Variety of Services Offered & 0.211 & 4.135 & $0.000^{* * *}$ & 1.333 \\
\hline Reasonableness of Price & 0.137 & 2.776 & $0.006 * *$ & 1.247 \\
\hline Convenience of Location & 0.208 & 3.954 & $0.000^{* * *}$ & 1.414 \\
\hline IT Application & -0.060 & -1.084 & 0.279 & 1.573 \\
\hline Employee Development & 0.108 & 1.700 & 0.090 & 2.046 \\
\hline Business Network Expansion & -0.091 & -1.781 & 0.076 & 1.348 \\
\hline
\end{tabular}

$\mathrm{R}^{2}=0.450, \mathrm{~F}=17.694, \mathrm{p}$-value $=0.000$

*** Significant at 0.001

** Significant at 0.01

* Significant at 0.05 
Table 5. Effects of Competitive Capabilities on Growth

\begin{tabular}{|l|c|c|c|c|}
\hline \multicolumn{1}{|c|}{$\begin{array}{c}\text { Strategic } \\
\text { Elements }\end{array}$} & $\begin{array}{c}\text { Standardized } \\
\text { Beta }\end{array}$ & t-value & p-value & VIF \\
\hline Reliability of Service & 0.178 & 3.384 & $0.001 * * *$ & 1.955 \\
\hline Speed of Service & 0.205 & 3.314 & $0.001 * * *$ & 2.709 \\
\hline Service Flexibility & -0.008 & -0.165 & 0.869 & 1.719 \\
\hline Service Safety & 0.050 & 1.066 & 0.287 & 1.557 \\
\hline Ease of Service Access & 0.201 & 4.740 & $0.000^{* * *}$ & 1.275 \\
\hline Rapid Customer Response & -0.006 & -0.114 & 0.909 & 1.852 \\
\hline Availability of Service Facilities & 0.139 & 2.724 & $0.007 * *$ & 1.853 \\
\hline Variety of Services Offered & 0.086 & 1.973 & $0.049 * *$ & 1.333 \\
\hline Reasonableness of Price & 0.152 & 3.630 & $0.000 * * *$ & 1.247 \\
\hline Convenience of Location & 0.122 & 2.735 & $0.007 * *$ & 1.414 \\
\hline IT Application & 0.106 & 2.247 & $0.025 *$ & 1.573 \\
\hline Employee Development & -0.018 & -0.331 & 0.741 & 2.046 \\
\hline Business Network Expansion & 0.044 & 1.019 & 0.309 & 1.348 \\
\hline
\end{tabular}

$\mathrm{R}^{2}=0.604, \mathrm{~F}=32.957, \mathrm{p}$-value $=0.000$

$$
\text { *** Significant at } 0.001
$$

** Significant at 0.01

* Significant at 0.05

Table 6. Effects of Competitive Capabilities on Corporate, Profitability, and Growth

\begin{tabular}{|l|c|c|c|}
\hline \multicolumn{1}{|c|}{ Strategic Elements } & Corporate Image & Profitability & Growth \\
\hline Reliability of Service & $\checkmark$ & $\checkmark$ & $\checkmark$ \\
\hline Speed of Service & $\checkmark$ & - & $\checkmark$ \\
\hline Service Flexibility & - & - & - \\
\hline Service Safety & - & $\checkmark$ & $\checkmark$ \\
\hline Ease of Service Access & $\checkmark$ & - & - \\
\hline Rapid Customer Response & $\checkmark$ & $\checkmark$ & $\checkmark$ \\
\hline Availability of Service Facilities & $\checkmark$ & $\checkmark$ & $\checkmark$ \\
\hline Variety of Services Offered & $\checkmark$ & $\checkmark$ & $\checkmark$ \\
\hline Reasonableness of Price & - & - & $\checkmark$ \\
\hline Convenience of Location & $\checkmark$ & - & - \\
\hline IT Application & $\checkmark$ & - & - \\
\hline Employee Development & - & & $\checkmark$ \\
\hline Business Network Expansion & & $\checkmark$ & $\checkmark$ \\
\hline
\end{tabular}




\section{Service Quality}

- Reliability of Service

- Speed of Service

- Service Flexibility

- Service Safety

- Ease of Service Access

- Rapid Customer

Response

- Availability of Service

Facilities

- Variety of Services Offered

\section{Marketing Capabilities}

- Reasonableness of Price

- Convenience of Location

\section{Management Capabilities}

- IT Application

- Employee Development

- Business Network

Expansion

Figure 1. Logistics Firms' Competitive Capabilities 